\title{
Coke is It: How Stories in Childhood Memories Illuminate an Icon
}

\author{
Kathryn LaTour, University of Nevada Las Vegas \\ Michael S. LaTour, University of Nevada Las Vegas \\ George M. Zinkhan, University of Georgia
}

This paper builds on consumer storytelling theory and childhood memory research by proposing that earliest childhood memory stories are useful for developing brand myths and providing relevance to iconic brands. This article investigates consumers' childhood memories with Coca-Cola and finds that memories from early childhood are more predictive and insightful for understanding current brand attitudes than memories coming from adolescence. A focus group is unable to elicit memories from as early in life as the childhood memory session. In addition, the memories elicited by the group interviewer are not as relevant and meaningful to participants. When participants read experiences coming from the childhood memory session, those who connect with the earliest childhood memory stories have the strongest attitudes toward Coca- Cola. A discussion describes how this research method aids in generating insights about iconic brands and brands aspiring to become iconic.

\section{Introduction}

Iconic brands are consumer brands that become "consensus expressions of particular values held dear by some members of a society" (Holt, 2004, p. 4). Cultural meanings permeate these brands. These brands associate strongly with the culture's values, needs, and aspirations (Cross, 2002). CocaCola, McDonald's, Budweiser are iconic American brands. A number of brands construct their meaning and brand myth by being the "rebel" or the anti-iconic brand, such as Mountain Dew, Red Bull, In-N-Out, Apple (Holt, 2003).

Brand meaning derives from a "distinct moment of mediation" between production and consumption which contributes to the "cultural significance" inherent in consumption (Hebridge, 1988). The "moments of mediation" often become the basis for consumer brand stories that consumers tell and retell as a means to communicate and reinforce their own identity (Woodside et al., 2008). Iconic brands are ubiquitous, and not every consumer story may necessarily result in deep insights about brand meaning. In addition, brands change their meaning over time, so it is important for the managers 
of iconic brands to recalibrate their strategies and adjust to how current consumers find meaning in the brand.

This research addresses the following questions: How and when is an iconic brand's meaning created? What specific myths are associated with the Coca-Cola brand? What research method is most effective in eliciting consumer memory stories? Is there a benefit for the brand to connect with consumer early memories? This research uses a storytelling research method, which eliciting consumers' early childhood memories informs (see Braun-LaTour et al., 2007). The elicited memories are reconstructions which represent how consumer, familial, and cultural values intersect in the creation of a brand myth. Identifying the origin myth for iconic brands is not only important for the iconic brand or product but also serves as a means to develop "rebel" or anti-iconic brands.

\section{Background}

\section{Iconic Brands}

Changing Coke is like God making the grass purple. Millions of dollars worth of advertising cannot overcome years of conditioning, or in my case, generations. The old Coke is in the blood. (From For God, Country \& Coca-Cola, p. 2, 355, 356)

The quote above represents the sentiment of many consumer reactions after Coca-Cola decided to change the flavor of its flagship product; thousands more boycotted and protested. To some extent, this strong reaction emerges because the Coke brand is strongly etched in the American culture. That is, Coke is perceived as a cultural icon, and consumers don't like the fact that management is tampering with this icon (and their memories associated with the icon). Consumers found it to be unthinkable that someone could change the Coca-Cola formula, a constant that had followed them throughout the course of their lives. To the die-hard consumers, Coke was not a brand owned by the company. Rather, it was owned by all Americans (Pendergrast, 2000). In brief, there is a strong, intangible link between the consumer and the iconic brand. Iconic brands, by creating an identity for themselves, provide identity to the whole society (Holt, 2004).

Holt (2003) argues that iconic brands are the result of the consumer interaction with the brand, the "breakthrough performance of the brand" and the stories that consumers share about their experiences with the brand, that eventually become mythic. Holt follows in the structuralist perspective (ala Levi-Strauss, 1977) that a brand myth exists to resolve contradictions in society. By tapping into a collective desire or anxiety, iconic brands develop a status that transcends functional benefits. The 
famous Coca-Cola ad from 1971, "I'd Like to Teach the World to Sing," voices a desire to overcome the deep divisions in American society created by the Vietnam War.

Holt (2003) further argues that brands do not become icons because of their consistent presence and marketing efforts. Instead, iconic brands emerge from the tension felt in a society. Such struggle or tension might be necessary for Heroic or Rebel brands, but may not necessarily be relevant for all brands. Generally, archetypal stories have been used as the foundation for the brand myth (see Hirschman, 2000), but there are limited numbers of these stories (Jung, 1919/ 1970). The novelist John Bender (2006) argues that literature serves to create myths. Some examples from this source include Robinson Crusoe, Frankenstein, and Dracula. In turn, films serve to popularize these myths. Woodside et al. (2008) list a number of brand-related myths ranging from the Loyalist to the Mother of Goodness to the Little Trickster. Just as literature or film create or popularize myths, popular brands can serve as the foundation for creating new myths. The brand helps consumers carry on the belief in the myth so that they behave according to its rules. Myth underlies the real; it is the apparitional quality of everyday experience and reveals the nature of social experience. The brand myth provides consumers perspective in which to enter the illusion to help "make sense" of everyday life (Woodside et al., 2008).

The success of Coca-Cola following the New Coke debacle may be due in part to the brand's personality as well as fitting a defined myth (American dream). The brand was able to recover so quickly because the market "knew" the brand to be sincere and when the company apologized for their "marketing mistake" consumers not only forgave them, but came back to them with reinvigorated passion. Aaker et al. (2004) find that brands built on more "sincere" personality traits fare better after such a public relations disaster, in comparison to a more rebellious or celebrity brand (who the consumers might love to hate).

The Coca-Cola Company has developed as an American icon but the region creating the brand embraces the icon most strongly - the Deep South. The growth of brand communities is one of the important results of developing an iconic brand (Muniz and O'Guinn, 2001), which adopt and perpetuate the myth. The backlash following introduction of New Coke was taken to an extreme in the Deep South; for example, one minister in rural Alabama led his congregation in prayer for the local bottler's soul, which was, he felt, undoubtedly destined for hell (Pendergrast, 2000).

\section{Building an Iconic Brand}

Iconic brands are developed over time, not born. They weave themselves into the fabric of everyday life. Early childhood exposure to a brand is a way to create an emotional attachment and 
solidify the relationship (see Braun-LaTour et al., 2007). "Attachment" is an inborn system in the brain that evolves in ways that influence motivational, emotional and memory processes with respect to significant others (Pillemer, 1998). Holbrook and Schindler introduce the concept of "peak period," and suggest in these peak periods (in the process of maturation) strong attachments to a brand or product are most likely to form (Holbrook and Schindler, 1996). For instance, consumers have a strong attachment to the musical styles that they are exposed to in late adolescence. However, Holbrook and Schindler (1996) focus on product categories (e.g., films, music, and politics) that are highly involving and associated with socially-influenced learning.

Brands must take into account the cultural biography of the brand when considering their own peak period for exposure (Olson, 1995). Forming attachments to food products may be different than more socially learned products like movies. In her research on consumer-brand relationships, Fournier (1998) surmises that relationships formed earlier in life, that were introduced by significant others, and held great emotional significance, were often those that resulted in the strongest consumer-brand bond. Ji (2002) also argues that relationships children form with brands early in life are more imbedded than those formed later in life. Lupton (1994), in surveying Australians' early memories of food, reports that their earliest memories were closely linked to familial relationships and that there was a symbolic aspect of food consumption where the meal is seen as representing home. Food relates often to one's group membership or kinship. The cultural anthropologist Clotaire Rapaille (2006) posits that Americans associate food with home as well, primarily the mother or traditional food preparer.

Building off the importance of early childhood exposure to brands or products, some marketing researchers focus on childhood memory stories as a means to uncover a brand's myth (Braun-LaTour et al., 2007). These researchers probed consumers' earliest and defining memories of automobiles and found each generation had different thematic memories. Because each generation grew up in a different cultural environment which had different values, different myths regarding the product resonated. The participants' earliest memories came from early childhood and lent insight into feelings for a "safe" family car, whereas the defining memories came from adolescence representing breaking away from parents, and independence and lent insight into desires for a more socially observable and self-defining sports car (Ibid). In other research, consumers who had early childhood exposure to a fast food brand were found to have stronger relationships built on the "sincere" family-oriented personality traits than those who formed their relationship with the brand during late adolescence and the brand's personality was built on the more "exciting" or rebel type personality (Braun-LaTour and LaTour, 2007). Depending on the type of early exposure one has with a brand, different brand myths may emerge. The 
question addressed in this research is what type of memory (earliest versus defining) yields the greatest insights into an iconic brand like Coca-Cola?

\section{Autobiographical Memory and Forming Emotional Connection to Consumers}

The research here strives to help both managers and consumer psychologists understand what type of consumer memory yields the most relevant brand stories. Consumers store their brand-related experiences in autobiographical memory. Autobiographical memory is a type of episodic memory; it is memory of things that define the self, the sum of experiences that make us who we are (Conway and Rubin, 1993). When people recall autobiographical events, they get a feeling of reliving the moment,

"seeing" the experience transpire in the mind's eye, and taking in the emotions of that event (Schacter, 1996).

Some advertisers recognize the emotional impact of connecting to consumer memories (Sujan et al., 1993). Triggering personal memories in marketing communicates benefits not only through the nostalgia created by the consumer recollection process but by also reinforcing the brand myth. Finding the right experiences to feature in these campaigns is therefore relevant to marketers seeking to personalize and keep relevant the brand's mythology.

Within the psychoanalytic literature which informs the childhood memory elicitation method (e.g., Adler, 1931), a focus on eliciting specific events occurs rather than more generic memories (Bruhn, 1985). Earliest memories that are quite clear and vivid are so because they are particularly important to an individual (Adler, 1931; Bruhn, 1985). The clearer and emotionally involving the earliest memory, the more likely those thoughts lend insight into present-day situations and attitudes (Bruhn, 1985). In Braun-LaTour et al. (2007) both specific and generic childhood memories were used to provide insights into the product myth, though they suggest that future research might consider disentangling these different types of recollections.

\section{Early Childhood Memory Study}

Fifty undergraduates (20 male, 30 female), average age 22, at a large southeastern university participated in this session for course credit. This sample seemed appropriate because $95 \%$ grew up in the Deep South and had the potential to be influenced by two prior generations who also consumed the product. Two days prior to the memory session, participants were told that they were to remember their earliest memories from childhood, and particularly, those involving Coca-Cola or another cola product as well as a memory that best "defined" Coca-Cola to them (no age constraint was given for 
that experience). They were asked to write these memories down and bring them to the session. This lead-time was given for two reasons: (1) so that the participants might benefit from hypermnesia (Schacter, 1996) and (2) to estimate the effectiveness of the memory probing exercise. The researchers here wanted to take advantage of techniques that might enhance the recollection process as different techniques may yield earlier and more important memories, so they incorporated relaxation, visualization and the memory surfacing techniques that Braun-LaTour et al. (2007) describe.

Following the guided session, participants wrote their "memory stories": they were requested to "Tell us about your memory (state date, place, who is involved, how you felt, and what happened). Please try to write several paragraphs." They were asked to rate their memories as to personal importance (1=trivial, 10=very important); their emotional involvement (1=nothing, $5=$ =xtreme) and how well they remembered the event, (1=not at all, 10=perfectly), adapted from Thompson et al. (1996). They also rated their memories on 27 feeling states (e.g., joyous, sentimental, proud, angry), adapted from Burke and Edell (1989) to yield positive/negative affect factors. They provided demographic information and loyalty status and rated Coke on four bipolar attitude scales (10 point), unfavorable-favorable, bad-good, unpleasant-pleasant, and negative-positive, and their likelihood of buying Coke in the future (also on a 10 point scale).

\section{Coding Technique}

The interpretation of the memory stories is discovery-oriented in nature (Wells, 1993). The verbatim reports of the memory stories and the initial thoughts and feelings served as the primary data in which categories and relationships were identified. An extensive and structured process was used to identify the key themes (as per Dey, 1999), or what the memory literature might deem as "generic events." The coders looked for deep metaphors (Johnson, 1987), latent meaning and affect (Barakett, 1999), and the generic action event (Barsalou, 1988) in each of the memory stories. The researchers also looked at these memories for their symbolic value and the brand myth that captured consumers' stories about the brand.

In addition, some specific quantitative coding of the stories occurred. The researchers coded whether the memory was newly surfaced in the memory session (in comparison to the ones the participants had brought in that day); whether the memory was written in the present or past tense; whether the memory represented a singular unique experience or one that was recurring; whether the experience occurred at home (inside, outside), at a relative's, or another locale; and who was involved in 
the memory (e.g., family, friends). Inter-rater reliability was high, and disputes were settled without much disagreement.

\section{$\underline{\text { Results }}$}

The Gen X sample's childhood collided with the introduction of New Coke. Many of the participants mentioned this "catastrophe." One recalled that her grandfather was "one of those" who stocked up his garage with cases of old Coke, another recalled hearing the local Georgia newscast which announced the introduction of the New Coke and gave locations where the old Coke could still be bought and how much each location was allowing consumers to buy. This sample was raised by generations who had also grown up with Coca-Cola, with one participant noting that it was "her" Coke (her mother's) in addition to having her own stories to share about the brand. Several participants' families collected Coca-Cola memorabilia. There was strong regional pride in the brand. One participant recalled that during kindergarten (and subsequent later years) the local Coca-Cola bottling plant from his town would come to his school's parking lot and pass out free Cokes as well as some school supplies. The majority of the sample had visited the World of Coca-Cola Museum (located in Atlanta) at least once. One said "It is something for us to identify with...it's important to have a business from our hometown that you grew up with, sense of pride and heritage in the celebration of the brand." Some participants had no idea of the global presence of the brand until they visited the museum. One participant said that even though she wasn't Catholic, one year she decided to give up something important to her for Lent, and she chose giving up Coca-Cola because of its importance in her daily life.

\section{General Properties of the Early Memories}

The earliest memories participants recalled occurred during what Piaget (1952) classifies as the early preoperational period (average age 4.7). Symbolic meaning and brand status have already been learned by this time in life (Hite and Hite, 1995). Although children are beginning to talk during this period of development, other sensory inputs prove to be more instrumental in children's understanding of their world during this preoperational stage, and the sensory detail in participants' initial statements and longer stories demonstrated that, as with this participant:

I was around 3 or 4 and at my grandma's house. I remember sitting at the table. My grandmother and mom were sitting around me. I had just eaten a graham cracker and was thirsty. My mom brought me back a drink in a sipping cup. I lifted it to my mouth and took a swallow. It burned my throat so to relieve a little tension I burped and my grandma and mom 
started laughing. I did not understand what they were laughing at, but I started to laugh and smile too.

These early memories are sensory-laden with, on average, an individual using at least two senses in their descriptions. The total number of sensory modalities used in describing the experience has been said to be an index of the richness of the reconstructed memories (Kihlstrom and Harackiewsk, 1982). Visual was the most used sense (75\%), followed by taste (67\%), touch (56\%), smell and auditory (10\% each).

The memory elicitation session was successful in surfacing memories that had not been aroused for some time $-78 \%$ were newly remembered after the memory regression session. One participant said, "I wouldn't have remembered the experience without the probing" another said he had "No idea" that he had memories of Coke that went so far back into his childhood, another commented that with the relaxation session he was able to "go back and see memories that he didn't normally see." In addition to surfacing new memories, these "memories" were often experienced in the present tense, with $45 \%$ writing their memories as if they were just happening, as with this participant:

My mother is wearing a blue paisley dress, and she's holding a little Coke bottle. Only adults drink Coke. I am 4 or 5. I'm playing with a doll and blocks on the first floor at her feet. There are two other people in the room.

Participants were asked what else was going on in the world when this memory transpired. Most of the responses revolved around their family situation. The "outside" world did not exert much influence, as typically found in this egocentric time of development (John, 1999).

\section{Typology of Early Experiences}

After reading the memory experiences, the coders developed a typology that describes the functional and symbolic role Coca-Cola played in consumers' lives by segmenting experiences based on who was involved in the memory and whether the memory was special or a recurring experience, these are presented in Fig. 1. Three key myths, associated with these experiences, include Transformer, Mother/Caretaker, and Hero.

Special family experience. The first quadrant represents those experiences that involved the consumer and close family members, particularly parents. These experiences are considered to be "special" because they represent a unique moment in time when the child and the parental figure bond. The focus of the memory is on the specific experience that brings the two together; one participant 
described having Coca-Cola with his father when he was 5 . He said that experience made him feel special, because he was brought to the dealership, not his brothers. These early memories represent a type of coming-of-age, where Coke is passed from generation to generation (literally as seen in the touch reference here), as with this participant:

It was a hot summer day and we went to my uncle's store. Mom got her bottle of Coke and shared it with me. It was a beautifully shaped bottle with water beads dripping off the sides. I remember tasting it and the fizz tickling my lips and nose a little. It was so refreshing and cool.

Note how that participant refers to the brand as "her mother's" bottle, and the experience represents her own first time tasting the beverage, which she typically associates with being older. In these coming-of-age memories, there is often a mother-daughter experience or a father-son experience. In other cases, Coke is mentioned as being a reward for good behavior, such as getting good grades in school. In these special parental bonding experiences, the underlying emotion is love and a feeling of belonging or acceptance. When participants are asked, "what other experiences come to mind after remembering this one?", most mention other camaraderie-type experiences or special moments with parental figures. Coke is often viewed as a reward or as a symbol of an accomplishment (e.g., growing up or maturing).

The brand myth that emerges from these memories is "Coke as Transformer," where the "passing of the torch" (Coke) from generation to generation (Moore et al., 2001) symbolizes the passing of a heritage, dubbed "sacralization through inheritance" (Belk et al., 1989). This heritage includes: Southern culture, family tradition, and role education (e.g., what it means to be a father or a mother). This myth has deep meaning to consumers and represents an idealized relationship between parent and child:

Summertime, hot, very sunny. In LaGrange, GA pull into a Sing Gas station and dad buying bottled Coke for he and I [sic]. He was telling me this is what he and his friends did when they were younger....buying bottled Coke from a gas station or small store, how cheap it was then.

In this case, the Coke brand serves as a way to strengthen the parent/child bond, as the two come together as equals in the sharing of the sacred totem. There is a symbolic dimension to sharing a brand across generations that expresses latent emotions of love and respect (Olsen, 1995). This special experience is reflected on later in life to reaffirm that bond, as discussed here:

I am very young (6 or 7). I am at the hunting camp in Mississippi with my Dad. All the men are taking the Coke and mixing it up with their whiskey. I have me a cup of Coke. I felt good. It was 
a feeling that I re-experienced after 21 , when I mixed me a drink at the same camp with many of the same men, from the same bar, with the same things.... I can remember the "old family." Our land, that we don't have anymore, and the camaraderie that is still found at the camp. I can remember the extreme dependence on my dad and that time that I still have a little of sometimes when we're still there.

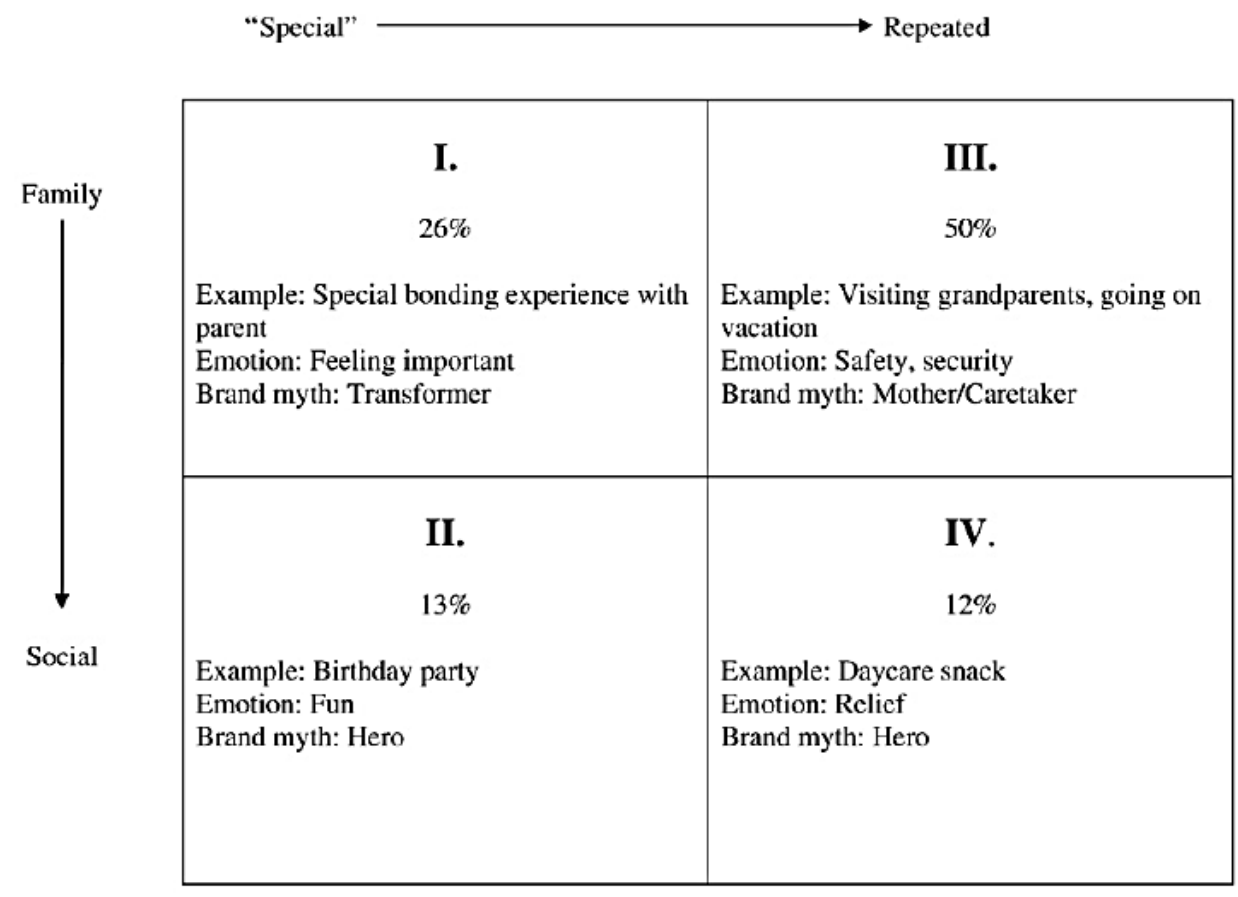

Fig. 1. Typology of early consumer experiences with coke.

Coke as a special social experience. For these participants, their special moment with Coke is more social in nature, with all of them remembering a special event (e.g., a birthday party):

I was at this boy's house in my first grade class, it was his birthday. There were Coke products set up on a table and his mom and other parents poured Coke into little glasses and we got to drink it. I remember thinking it was a big deal that I got to drink it. That's when I associated Coke with a treat.

Participants mentioned having to usually drink milk or juice at home and that at the party Coke was "dressed up" in festive colored cups and made the occasion special. These special occasions are often associated with the emotions "happiness" or "excitement" and "playful" experiences. In this context, the soft drink is viewed as a special treat. All these experiences transpire outside the home and in the presence of peers, rather than family members. These memories also reveal the prominence of 
the brand in social events. Similar to the situation of repeated social experiences (Quadrant 4), Coke is seen as a "Hero." In this particular case, the iconic brand saves the birthday party from the boring food and drink that is served. As a result, the participant is able to do something he might not normally be able to do.

Coke as a ritualistic family event. These experiences result from events that are repeated and subsequently merge together in consumers' minds. For example, some experiences are tied to family rituals (e.g., a family trip to grandma's house), while others are tied to a specific place (e.g., a favorite restaurant where the family always goes to order pizza). In these settings, Coke is seen as a complement to the family event.

Some experiences became so ritualized, that Coke came to symbolize the person associated with Coke experience, usually grandparents, like this participant:

I'm 3 or 4, grandmother used to always have bottles of Coke at her house, I see her kitchen. She would also make peanut butter and jelly sandwiches. With some cheese curls. She always had Coke every time I went there.

Just as in the case of the memories outlined in Quadrant I (special parent bonding experiences), the brand serves as a representation or symbol that creates a bridge between generations (Douglas and Isherwood, 1979). Some stories of this type fit into the pattern of the Transformer myth, as mentioned earlier. For instance, the family tradition of throwing peanuts in a Coke bottle was introduced by one participant's uncle.

However, another myth is apparent in these memories. This second myth is Coke as the "Mother/Caretaker." The early memories associated with this myth take place inside - either at the participant's own home or at a grandparent's home. A deep metaphor ("container") is present in these memories. Here, the "container" represents a place where everything is safe, secure and predictable (Johnson, 1987), and the dominant emotion is a feeling of safety or being comforted. Psychotherapists report that early memories which bring a feeling of being warm and snug tap into the manner in which a patient experiences security, emotional comfort and basic ego-relatedness (Winnicott, 1953). Coke is viewed in these early memories as being part of a secure and safe world. Coke is an instrument that provides comfort.

Ritualistic social events. The memories in this quadrant are the least common, and are the least strongly-held. Few consumers in this quadrant currently rate Coke as their loyal brand. Experiences in 
this group include: drinking Coke at daycare; drinking it with a snack at a friend's house; or sharing a Coke on a typical afternoon while visiting with neighbors.

All these experiences take place outside the home, and, for some, the experience is not a happy one to remember, as with one person reports being served Coke in a daycare-he hated the experience. Coke is seen by these individuals as a coping mechanism-away to get through daycare or after-school care, or away to cope with being away from home while at camp. Like the more "special" social experiences, the brand myth that best represents Coke's role in these memories is that of a Hero. The hero can serve a variety of roles. On the one hand, the hero can (temporarily) release the participant from the sad tone that generally surrounds life. Coke can stand out as one bright spot in an otherwise boring party. On the other hand, the iconic brand allows the consumer to do things or experience things that are beyond the ordinary.

\section{Explanatory Power of the Earliest Memory}

Quantitative analysis can add elucidation to qualitative analysis (Strauss and Corbin, 1988). Towards that end, the relationship between how consumers felt about their earliest Coca-Cola experience and how they presently feel about Coca-Cola is investigated. The sample includes 36 participants who had recalled an earliest memory involving Coca-Cola. Two indicators of "emotional importance" were combined a) personal importance of the brand and b) emotional involvement with the brand. The positive affect measures are adapted from Burke and Edell (1989) and result in a Cronbach Alpha of .95. The present-day attitude measures were averaged (Cronbach Alpha=.94), and the likelihood of purchasing is used as a behavioral indicator. It is predicted that the emotional importance of the experience will be a driver of positive affect.

The fit of the model is acceptable as Fig. 2 shows. Earliest Memory of Coca-Cola is a good (indirect) predictor of present-day attitude and behavior. That is, the effect of Early Experience operates through Affect and Attitude. All paths Fig. 2 are significant (pb.05). The results reveal a "sequential" pattern. These results show that affect manifestation is key for attitude formation resulting from early product experiences.

\section{Brand Defining Memory}

The quadrant system that we propose in Fig. 1 can also be applied to the concept of "brand defining memory." The relationship between self and others is a prevalent marker of the defining memory, and the themes of Coke as a special treat or bond are also common. This memory type, 
however, shows more external social influences, with the "other" in the relationship extending beyond close family members, so there are more memories that fit into Quadrants 2 and 4.

Less sensory detail occurs in the defining memory; most participants use only one or two senses to describe their experience. Unlike the earliest memories, when asked about what else was going on in their lives, participants are able to name cultural and social functions beyond the family, such as who was president, their favorite musical group, and what movies they had seen.

The brand defining memory occurs later in childhood (average age 10), after the cola had had an opportunity to exert its personality and define itself. Children in this concrete operational stage (7-11) are beginning to use generalizations and their developed schema (Piaget, 1952). In fact, several people mentioned expectations (both being met and not being met) as their brand defining memory, indicating that the brand schema had already been well in place, such as wanting Coke when offered Pepsi. Over half of the memories revolved around Coke initiated activities, such as the ad campaign "I'd like to teach the world to sing," Olympic sponsorship/involvement, the New Coke fiasco, Word of Coke museum, and wearing/buying Coca-Cola merchandise. Compared to the earliest memory, only $32 \%$ of the brand defining was "new" within the memory session.

The goal was to see if the brand defining memories would serve to explain present-day attitudes and behavior, as the earliest had been. Consumer socialization researchers (Moschis, 1981) and nostalgia researchers (Holbrook and Schindler, 1996) might predict that the affect generated from these later memories would be more associated, while early-memory researchers would predict the opposite. As in the case with earliest memory, the ratings of personal importance and emotional involvement were highly correlated $(r=.68)$ and served as the representation of the overall emotional importance of defining memory experience, the positive affect measures again were combined (Cronbach Alpha of .94). However, the same tight relationship as found with the earliest memory was not found (see bottom of Fig. 2).

Specifically, while the fit of the data to the model is adequate, the only significant paths are between emotional importance and positive affect and between attitude and likelihood of purchase. There is a "disconnect," as there is no significant path from affect and emotional importance to any subsequent variables. In contrast to the early memory context, the defining memory approach does not result in the sequence of variable relationships that is reported for earliest memories. As a result of comparing the two approaches, these results show it is important for researchers to evoke early memories that are emotionally important. That is, the defining memories are not as useful, either for researchers or for managers. 
MODEL 1: RELATIONSHIP BETWEEN EARLEST MEMORY OF COKE AND PRESENT-DAY ATTITUDE

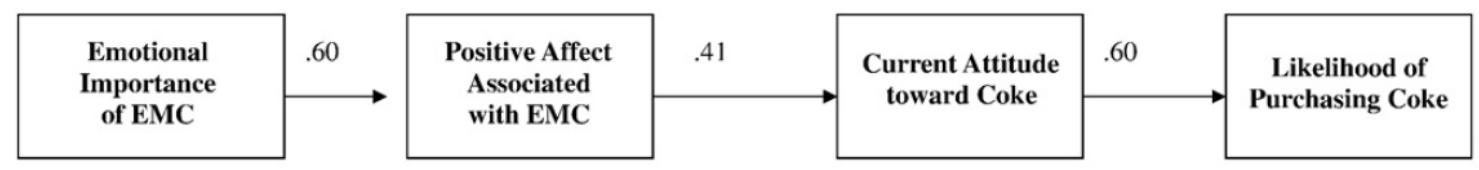

MODEL 2: RELATIONSHIP BETWEEN BRAND DEFINING MEMORY AND PRESENT-DAY ATTITUDES

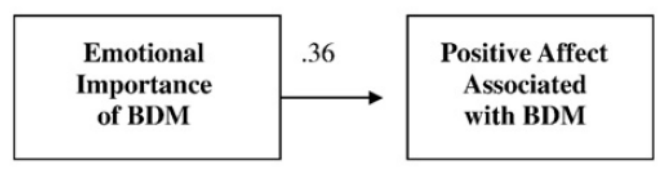

Model 1 Fit Indices

All paths are significant at the $\mathrm{p}<.05$ level.

Chi Square $=1.32$

$\mathrm{DF}=3$

$\mathrm{p}=.724$

Normed fit index $=.996$

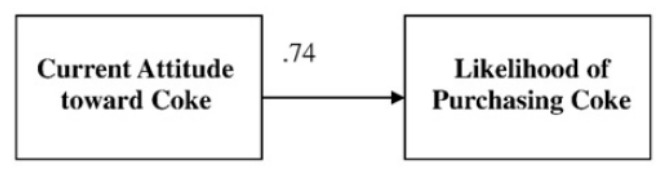

Model 2 Fit Indices

All paths shown are significant at the $\mathrm{p}<.05$ level.

Chi Square $=5.17$

$\mathrm{DF}=3$

$\mathrm{p}=.160$

Normed fit index $=.988$

Fig. 2. A comparison of two models.

\section{$\underline{\text { Discussions }}$}

Consumers find recounting a variety of idiosyncratic experiences relating to their childhood experiences to be a relatively easy task. As basic commonalities exist, a $2 \times 2$ grid (see Fig. 1) summarized these experiences efficiently. In addition, these experiences are not "random," in terms of meaning. In Fig. 2, a sequential order through which early memories shed light on present-day attitudes and behavior is demonstrated. These early memories are more important in this regard than experiences occurring later in life for understanding current brand attitude. The importance of the early memory is also demonstrated through other means (e.g., the formation of brand myths).

Three myths loom large in consumer memory in this case - Transformer, Mother/Caretaker, and Hero. Other food products likely also relate with the Caretaker Myth (e.g., grandmother's spaghetti, mother's chicken soup). However, both the Transformer and Hero myth may be somewhat rare for a food product. Under the Transformer myth, the iconic brand serves as a totem for passing power or tradition from one generation to another. This specific instance of transformation or transfer serves as a defining life moment. Under the Hero myth, the iconic brand has the power to create one bright moment in an otherwise dismal day. It is interesting to note that this myth follows rather closely some of the ad campaigns that Coca-Cola has sponsored over the years.

The extent to which these types of memories would emerge when applying more traditional research methods is important. Are the findings of the early memory session more revealing for managers than other methods? The next two studies address these questions. 


\section{Focus Group}

A focus group was conducted in order to learn whether the experiences elicited through the childhood memory study could be uncovered just as easily with a more traditional method. The eleven participants ( 4 male, 7 female, with an average age of 21 ) were drawn from the same population as the early memory study, with an emphasis on Coca-Cola loyalists.

The session began with a short survey that asked them to write about their earliest memory of Coca-Cola and rate it on a number of scales (the same ones used in the prior study). A discussion of these early Coca-Cola memory experiences began the session. After each memory was shared, the moderator asked the group if they could relate at all to these experiences. The group members then discussed what memories/experiences they thought were most important in determining their relationship with the brand. Participants then discussed Coca-Cola's advertising. The session ended with the moderator asking participants to close their eyes and listen to some descriptions of experiences (which were elicited in the early memory study) and to raise their hand if they could picture themselves having that same experience.

Differences in the memories elicited in the focus group and the early memory study occur. For instance, 7years is the average age for the earliest memory reported here (which is older than the 4.7 years in the first study). The majority of these memories were experiences that happened many times (9) rather than unique situations. There was less detail or richness in the reported memories than in the early memory study and not as many contextual details present. A description of the underlying emotion or feeling of the experience was also lacking.

The only person's memory that participants responded to in a favorable way was Hillary, who said that she drank Coca-Cola because her mom drank the brand. Note that some of the themes surfaced in the early memory study were found here such as the ritual of having Coke in the same place and the special one-on-one outing with a parent. The difference was that these experiences were not articulated to the same degree as the prior study, and that some of the early memories were not mentioned, such as visiting grandparents, attending birthday parties, family vacations.

When the participants were asked what experiences that they thought were most important to their relationship with Coke, they told a different story. The experiences these participants most associated with Coke were: drinking Coke at high school sporting events; having Coke at family reunions; drinking Coke at the movies. They also thought experiences such as ordering Coke and being told they only have Pepsi, or having a family member scold them for buying another cola, were particularly 
defining of the brand. It is noteworthy that these experiences are similar to the brand defining ones mentioned in the prior study.

All participants grew up in families where their parents and grandparents drank Coke. None of them had any restrictions regarding drinking Coke when they were children. This result reinforces our finding in the early childhood memory study regarding intergenerational influences; however, in the focus group, participants were not able to articulate when or how their parents or grandparents introduced them to Coke. As described by Ben: "It was hard. I don't think about my first Coke experience a lot. It's just sort of a random thing. It's just sort of tough to recall. It doesn't really stick out because it's been so consistent (always Coca-Cola)."

This focus group also probed memories of Coca-Cola advertising. Because of the reconstructive nature of recall, there is the possibility that experiences or images associated with the advertising would become part of consumers' own personal memories of Coke (note how Ben uses the slogan "Always Coca-Cola" above). The Coke ads did not prove to be memorable. Coke's association with movie theatres was mentioned, but no specific campaign recalled.

When they were asked to listen to some experience descriptors coming from the early memory study, there was much more agreement in the group. Six people said they could relate to the experience of having Coke when visiting grandparents; seven said they could remember having Coke at birthday parties as a child; seven recalled sharing a Coke with a parent as a reward; ten remembered having Coke as part of a family vacation. These early memory experiences resonated much more than the ones they themselves had recalled.

The memories elicited in the focus group were not young or as detailed as those surfaced in the childhood memory study. In addition, the early memory study put the Coke memory in context; the memory surfacing task helped consumers surface sensory information (e.g., other experiences occurred during the same as their first exposure to Coke). These more detailed memory descriptions provide advertisers concrete images or cues to include in their advertising to help draw consumers back to that critical time of their life. Had the moderator listened to what experiences focus group participants thought were most important to their relationship with Coke, the early experiences would have been missed. 


\section{Follow-Up Survey}

Were the memories that surfaced in the childhood study "better" and more useful for advertisers than the experiences recalled in the focus group (e.g., in terms recreating positive, childhood experiences and perpetuating the brand myth)?

One hundred six (49 female, 57 male) participants, with an average age 22.3, were drawn from the same population as the other two studies. A survey was designed to determine what experiences brought back the most memories of Coke: those surfaced in the childhood memory session, those surfaced in the focus group, or those experiences featured in recent advertising efforts. See Table 1 for the experiences used to represent each group.

Participants were given a list of these twelve experiences and were asked to pick the one that brought back the most memories involving Coca-Cola, and then to write about their experience. They then were asked to recall as many Coca-Cola ads as they could remember. They rated their attitude towards Coca-Cola on four ten-point bipolar scales. They rated their likelihood of buying Coca-Cola in the future, whether or not their parents and/or grandparents drank Coca-Cola, and if access to CocaCola was easy or very restricted during their childhood.

The expectation was that the experience descriptors taken from the childhood memory study would yield the most recollections; this was found, but not significantly so (see Table 1 for the results and statistics). However, differences occur in the memories each experience- type aroused. The earlymemory experiences yield a much younger age association with the memories than the other two groups. Those who used the early memory experiences to recollect their past reported more favorable attitudes toward Coke than the other groups, and greater likelihood to buy the brand in the future.

None of these groups recalled many advertisements ( $M=1.5$ ads overall) nor does a difference occur between these groups in terms of accessibility to Coke as a child. Overall, $86 \%$ of participants reported easy access, so it was not the amount of exposure to advertising or the product that differentiated them. What was more telling was the exposure to Coke from parents and grandparents. Those reporting memories consistent with the experiences surfaced in the early childhood memory study had more chances for intergenerational influence, with more of these participants having parents and grandparents that drink Coke.

This survey shows that stories elicited in the childhood-memory session were effective cues to help consumers recall their own early childhood with Coca-Cola. The memories from the childhoodmemory session yielded earlier childhood memories than those experiences coming from the focus 
groups or advertising. This finding means that advertising featuring these experiences increases the possibility of uncovering critical brand moments for other consumers.

Table 1

Survey results.

\begin{tabular}{|c|c|c|c|c|}
\hline Measures & $\begin{array}{l}\text { Early childhood } \\
\text { memory session: } \\
\text { birthday parties, } \\
\text { visiting grandparents, } \\
\text { family vacation and } \\
\text { special one-on-one } \\
\text { outing with a parent }\end{array}$ & $\begin{array}{l}\text { Focus group session: } \\
\text { family reunion, being } \\
\text { told "No Coke, only Pepsi" } \\
\text { in a restaurant, attending } \\
\text { a high school sporting event, } \\
\text { and having a family member } \\
\text { scold you for buying a cola } \\
\text { other than Coke }\end{array}$ & $\begin{array}{l}\text { Recent advertising } \\
\text { experiences: Coke's "Life } \\
\text { Tastes Good" campaign; } \\
\text { these were having a Coke at } \\
\text { a family or friend's wedding } \\
\text { and having a Coke at a rock } \\
\text { concert; "hoarding Coke" } \\
\text { from family members, which } \\
\text { was featured in an ad with } \\
\text { Courtney Cox, having Coke } \\
\text { at the movies }\end{array}$ & Statistics \\
\hline $\begin{array}{l}\text { \% using these experiences } \\
\text { in their own recall }\end{array}$ & $43 \%$ & $36 \%$ & $20 \%$ & n.s. \\
\hline Age of recalled experience & 5.6 & 13.7 & 11.6 & $\begin{array}{l}F(2,98)=50.89, p<.0001 \text {, post hoc } \\
\text { tests found childhood group } \\
\text { significantly younger than other two }\end{array}$ \\
\hline Attitude toward Coke & 9.1 & 8.01 & 7.2 & $\begin{array}{l}F(2,105)=8.7, p<.0001 \text {, post hoc } \\
\text { tests found childhood groups } \\
\text { significantly higher than other two groups }\end{array}$ \\
\hline Likelihood to Buy & 9.6 & 8.6 & 7.7 & $\begin{array}{l}F(2,105)=7.34, p<.001 ; \text { post hoc } \\
\text { tests found childhood group significantly } \\
\text { higher than other two groups }\end{array}$ \\
\hline$\%$ parents drink Coke & $89 \%$ & $63 \%$ & $77 \%$ & $\begin{array}{l}\chi^{2}(N=106)=8.01 p=.02 \text {; comparison } \\
\text { between childhood and other groups: } \\
\chi_{(\mathrm{N}=106)}^{2}=6.4 p=.01\end{array}$ \\
\hline \% Grandparents drink Coke & $80 \%$ & $56 \%$ & $50 \%$ & $\begin{array}{l}\chi_{(N=106)}^{2}=8.15 p=.02 ; \text { comparison } \\
\text { between childhood and other groups: } \\
\chi_{(N=106)}^{2}=7.87 p=.005\end{array}$ \\
\hline
\end{tabular}

\section{Discussion}

This paper attempts to increase understanding of childhood memory stories, as they relate to an iconic brand. The first study demonstrates how different types of childhood memories map onto different brand myths for Coca-Cola. In addition, early-childhood memory research is extended by validating whether or not consumers' earliest memories of a brand provide meaning to present-day attitudes. In Fig. 2, the early memories relate most to present-day attitudes and behavior than the later "brand-defining" memories. The focus group discussion shows that the early memory experiences surfaced via relaxation, visualization and a memory surfacing task were not accessible with this traditional method. The survey demonstrates that, when consumers use the early experiences surfaced from the childhood memory session to recall their own past, they are more likely to surface younger experiences, have more positive attitudes toward the brand, and be more likely to purchase the brand in the future.

In Fig. 1, the early-memory experiences are grouped into four categories with each category containing unique action events and underlying emotions that a manager might incorporate into a promotional campaign in order to reinforce a brand myth. Quadrant 1 features "coming of age" or 
special bonding experiences with parents. In turn, these experiences are accompanied by feelings of accomplishment, and the brand serves the role of Transformer. Quadrant 2 features special events (e.g., birthday parties), which focus on "play" and feelings of excitement. In this setting, Coke plays the role of Hero, and enables consumers to partake in a special treat. Quadrant 3 features family rituals (e.g., vacations, visiting with grandparents), and these settings are associated with feelings of security. As such, the Transformer myth also operates in this setting. In addition, the Mother/Caretaker myth also emerges in this quadrant. Quadrant 4 features every-day, out-of-the-home activities (e.g., daycare). Here, Coke also emerges as the Hero that helps consumers survive in a difficult or detached environment.

Early cola memories (for other brands) fit the same pattern, thus indicating that a competitor might successfully make connections to these earliest associations. For example, a non-Coke drinker in the first study had the following early memory:

My earliest memory of a cola was RC. I was around the age of 3 or 4 . Every afternoon ... my granddaddy and daddy would go out to the tractor shed to work and I usually went with them.

On Saturdays we would eat lunch in the field and it would be a cold RC and Vienna sausage.

Due to the reconstructive nature of memory, even if the experience was originally formed with one cola, another cola could convince consumers that the experience included their cola through advertising (see Braun, 1999). Reconstruction may be more likely for those consumers whose early experiences already represent summarized experiences, as those in Quadrants 3 and 4 . The Coca-Cola brand's "sincere" personality is naturally associated with the experiences appearing in Quadrants 1 and 3 that are family-oriented. Brand managers (in this category and in others) might use such "family experiences" to enhance the sincere, authentic, and family-oriented aspect of their own brand image. Alternatively, a brand manager might pursue a more rebellious myth by altering some of the circumstance of the memory. As an example, a "rebel soda brand" might highlight a birthday party serving the status quo beverage and showing some of the kids breaking away and sneaking another brand of cola.

The percentage of the type of experiences that appear in each quadrant of Fig. 1 would vary from product to product. Nonetheless, because these axes are based on general properties of autobiographical memory, the general figure can be used across products. Despite the fact that other methods (e.g., group interviews) may surface experiences consistent with these quadrants, it is the early memory experiences that define and guide the consumer's relationship with the iconic brand. In 
addition, managers are provided with guidelines to judge whether the memory experiences they are extracting from consumers may be meaningful, such as the amount of sensory detail; the tense of the story; the degree of emotional attachment indicated by touch and inclusion of close family members; and whether the experience is unique or repeated.

Past research on iconic brands (Holt, 2003, 2004) focuses on how the brand myth can resolve tension in a society. Myths do not necessarily need to be born from tension. Holt $(2003,2004)$ argues that consistency can kill a brand, and this advice runs counter to the spirit of the "Always Coca-Cola" slogan and brand heritage. Keller (1999) argues that consistency is necessary for long-term brand management. The caveat shown here is that the brand can maintain consistency while also adopting and changing as consumers' lives change. Products for which there is an emotional attachment and are with consumers at different points in their life narrative should reflect the notion of temporal change and stability (Markus and Wurf, 1987). An iconic brand, therefore, could facilitate self-continuity by connecting a person with a desirable past (e.g. memories), a present self (me now), or a future self (who I am becoming) (Kleine et al., 1995, p. 328) Whether Coca-Cola maintains its iconic status depends on its ability to continue to form meaningful relationships with consumers and be used by consumers to help in making sense of their own identity.

Following Olsen's (1995) prediction, brands must take into account the cultural biography of the brand when considering their own peak period for exposure. To extrapolate to the intergenerational effect of attachment on early product exposure, it appears that the affect drawn from that first Coke (or cola) experience is "imprinted" for preference later in life. Family ritual events that include Coke, such as summer vacations or visiting grandparents, may be the most effective experiences to bring forth in remembered attachments. By reminding consumers of imprinting family experiences with the brand and Coke's role as Mother/Caretaker, such reminding can do more than just make the consumer feel "nostalgic" - they can regenerate the brand myth and build equity.

\section{References}

Aaker J, Fournier S, Brasel AS. When good brands do bad. J Consum Res 2004; 31:1-16 (June).

Adler A. What life should mean to you. New York: Grosset \& Dunlap; 1931.

Barakett, L.A. (1999). The latent organization of salient memories: A psychoanalytic perspective. Dissertation, Auburn University. 
Barsalou LW. The content and organization of autobiographical memories. In: Neisser U, Winograd E, editors. Remembering reconsidered: ecological and traditional approaches to the study of memory. Cambridge: Cambridge University Press; 1988. p. 193-243.

Belk RW, Wallendorf M, Sherry JF. The sacred and the profane in consumer behavior: theodicy on the odyssey. J Consum Res 1989; 16:1-38 (June).

Bender J. The novel as modern myth. University of Nevada, Las Vegas, October: University Forum presentation; 2006. 6 .

Braun KA. Post-experience effects on consumer memory. J Consum Res 1999; 25:319-34 (March).

Braun-LaTour KA, LaTour MS. Using childhood memory elicitation to gain insights into a brand at a crossroads: The In-N-Out burger situation. Cornell Hotel Restaur Adm Q 2007; 48(3):246-73.

Braun-LaTour KA, LaTour MS, Zinkhan GM. Using childhood memories to gain insight into brand meaning. J Mark 2007; 71:45-60 (April).

Bruhn AR. Very early memories as a projective technique - the cognitive-perceptual method. J Pers Assess 1985; 49:587-97.

Burke MC, Edell JA. The impact of feelings on ad-based affect and cognition. J Mark Res 1989; 16:69-83 (February).

Conway MA, Rubin D. The structure of autobiographical memory. In: Collins AF, Gathercole SE, Conway MA, Morris PE, editors. Theories of memory (103-138). Hillsdale, NJ: Erlbaum; 1993.

Cross M. A century of American icons. Westport, CT: Greenwood Press; 2002.

Dey I. Grounding grounded theory: Guidelines for qualitative inquiry. San Diego: Academic Press; 1999. Douglas M, Isherwood B. The world of goods. New York: Basic Books; 1979.

Fournier S. Consumers and their brands: developing relationship theory in consumer research. J Consum Res 1998; 24:343-73 (March).

Hebridge D. Hiding in the light. New York: Comedia; 1988.

Hirschman E. Heroes, monsters, and messiahs. New York: Andrews McMeel; 2000.

Hite CF, Hite RE. Reliance of brand by young children. J Mark Res Soc 1995;37:185-94 (April).

Holbrook MB, Schindler RM. Market segmentation based on age and attitude toward the past: concepts, methods, and findings concerning nostalgic influences on customer tastes. J Bus Res 1996;

37:27-39 (September).

Holt DB. What becomes an icon most? Harvard Bus Rev 2003; 3:43-9.

Holt DB. How brands become icons. Cambridge, MA: Harvard University Business School Press; 2004. 
Ji MF. Children's relationships with brands: "true love" or "one night" stand? Psychol Mark 2002; 19(4):369-87.

John DR. Consumer socialization of children: a retrospective look at twenty-five years of research. J Consum Res 1999; 26:183-212 (December).

Johnson $\mathrm{M}$. The body in the mind: the bodily basis of meaning, imagination and reason. Chicago: University of Chicago Press; 1987.

Jung, C.G. (1970). Collected works, civilization in transition, vol. 10. (G. Adler \& R.F.C. Hull, Edited and Translated). Princeton, NJ: Princeton University Press. (Original work published 1919).

Keller KL. Managing brands for the long run: brand reinforcement and revitalization strategies. Calif Manag Rev 1999; 41(3):102-24.

Kihlstrom JF, Harackiewsk JM. The earliest recollection: a new survey. J Pers 1982; 50: 134-48.

Kleine SS, Kleine III RE, Allen CT. How is a possession 'me' or 'not me?' Characterizing types and an antecedent of material possession attachment. J Consum Res 1995; 22:327-43 (December).

Levi-Strauss C. Structural anthropology. Viking; 1977.

Lupton D. Food, memory and meaning: the symbolic and social nature of food events. Sociol Rev 1994; 42(4):665-85.

Markus H, Wurf E. The dynamic self-concept: a social psychological perspective. In: Rosenzweig MR, Porter LW, editors. Annual Review of Psychology, vol. 38. 1987. p. 299-337.

Moore ES, Wilkie WL, Lutz RJ. Passing the torch: intergenerational influences as a source of brand equity. J Mark 2001; 66:17-37 (April).

Moschis GP. Patterns of consumer learning. J Acad Mark Sci 1981; 9:110-27 (Spring).

Muniz Jr AM, O'Guinn TC. Brand community. J Consum Res 2001; 27:412-32 (March).

Olsen B. Brand loyalty and consumption patterns: the lineage factor. In: Sherry JF, editor. Contemporary marketing and consumer behavior: an autobiographical sourcebook (245-281). Thousand Oaks, CA: Sage Publications; 1995. p. 245-81.

Pendergrast M. For God, country and Coca-Cola. New York: Charles Scribner's Sons; 2000.

Piaget J. The origins of intelligence in children. New York: International Universities Press; 1952.

Pillemer DB. What is remembered about early childhood events? Clin Psychol Rev 1998; 18:895-913 (December).

Rapaille CG. The culture code. New York: Broadway Books; 2006.

Schacter DL. Searching for memory. New York: Basic Books; 1996.

Strauss A, Corbin J. Basics of qualitative research. Thousand Oaks, CA: Sage; 1988. 
Sujan M, Bettman JR, Baumgartner H. "Influencing consumer judgments via autobiographical memories: a self-referencing perspective.". Journal of Marketing Research 1993;30(November):422-36.

Thompson CP, Skowronski JJ, Larsen SF, Betz A. Autobiographical memory: remembering what and remembering when. Mahwah, NJ: Lawrence Erlbaum Associates; 1996.

Wells W. Discovery-oriented consumer research. J Consum Res 1993; 19:489-504 (March).

Winnicott DW. The capacity to be alone. In: Winnicott DW, editor. The maturational process and the facilitating environment. Madison, CT: International Universities Press; 1953. p. 29-35.

Woodside A, Sood S, Miller KE. When consumers and brands talk: storytelling theory and research in psychology and marketing. Psychol Mark 2008; 25(2):97-125. 